\title{
Pengaruh Perubahan Ukuran Citra terhadap Kinerja Metode Robust Regression pada Pengenalan Wajah
}

\author{
Budi Nugroho ${ }^{1}$ \\ ${ }^{1}$ Program Studi Informatika, Universitas Pembangunan Nasional "Veteran" Jawa Timur \\ budinugroho.ifeupnjatim.ac.id
}

\begin{abstract}
Abstrak- Penelitian ini membahas tentang pengenalan wajah yang dipengaruhi oleh faktor iluminasi, yang merupakan salah satu faktor utama yang mempengaruhi kinerja pengenalan wajah. Faktor iluminasi citra disebabkan oleh kondisi pencahayaan pada saat proses akuisisi citra. Kondisi pencahayaan citra berkaitan erat dengan kekontrasan citra, yang dapat berubah ketika citra mengalami perubahaan ukuran. Secara teoritis, perubahan ukuran citra akan mengubah tingkat kekontrasannya, sehingga akan mempengaruhi kinerja pengenalan wajah. Pada penelitian ini, pengaruh perubahan ukuran citra terhadap kinerja pengenalan wajah akan diuji secara empiris. Proses pengenalan wajah menggunakan metode Robust Regression. Metode ini memiliki kinerja yang sangat baik pada pengenalan wajah yang dipengaruhi oleh variasi iluminasi. Proses pengujian menggunakan salah satu basisdata citra wajah standar, yaitu AR Face Database, dengan memilih citra wajah yang berkaitan dengan faktor pencahayaan. Kumpulan citra wajah terbagi menjadi 4 kondisi pencahayaan yaitu rendah, sedang, tinggi, dan ekstrim (sangat tinggi). Proses pengujian dilakukan untuk menentukan kinerja pengenalan wajah menggunakan metode Robust Regression dengan ukuran citra latih yang berbeda (100x100 piksel dan 50x50 piksel) pada setiap kondisi pencahayaan. Hasil uji coba menunjukkan bahwa kinerja pengenalan wajah mengalami penurunan ketika ukuran citra diperkecil dari 100x100 piksel menjadi 50x50 piksel pada kondisi pencahayaan rendah, sedang, dan tinggi. Tetapi, pada kondisi pencahayaan ekstrim, kinerja pengenalan wajah justru mengalami kenaikan. Secara keseluruhan, dengan menggunakan ukuran citra 100x100 piksel, rata-rata akurasi pengenalan wajah sebesar $81,71 \%$. Sedangkan dengan menggunakan ukuran citra 50x50 piksel, rata-rata akurasi pengenalan wajah sebesar $\mathbf{8 0 , 8 8 \%}$. Rata-rata penurunan akurasi yang disebabkan oleh perubahan ukuran citra dari $100 \times 100$ piksel menjadi $50 \times 50$ piksel adalah $0,84 \%$. Hasil penelitian ini memberikan informasi penting bahwa perubahan ukuran citra mengakibatkan perubahan kinerja pengenalan wajah, dimana ukuran citra yang diperkecil akan menyebabkan penurunan kinerja pengenalan wajah.
\end{abstract}

Kata Kunci- Pengenalan Wajah, Faktor Iluminasi, Robust Regression, AR Face Database dan Ukuran Citra.

\section{Pendahuluan}

Proses pengidentifikasi seseorang sangat penting untuk dilakukan, khususnya berkaitan dengan pembuktian keaslian individu dan pengelolaan hak akses terhadap fasilitas penting [1]. Hal ini diperlukan untuk memastikan bahwa akses fasilitas penting yang bersifat terbatas hanya dapat dilakukan oleh orang yang berhak. Untuk memenuhi kebutuhan tersebut, teknologi biometrik dikembangkan untuk mendukung proses pengidentifikasi secara lebih cepat dan akurat dibandingkan mekanisme konvensional.

Salah satu teknologi biometrik yang banyak dikembangkan saat ini adalah sistem pengenalan wajah. Dibandingkan dengan pendekatan biometrik lainnya, pengenalan wajah memiliki sejumlah kelebihan dan lebih mudah untuk digunakan. Dalam proses pengambilan data, sistem ini hanya membutuhkan kamera meskipun kemampuannya sederhana dan harganya relatif murah. Tentunya dengan menggunakan kamera yang memiliki spesifikasi tinggi, kemampuannya untuk mengambil data akan menghasilkan kualitas citra wajah yang lebih baik pula. Data wajah dapat diperoleh dengan mudah meskipun dari jarak jauh.

Pendekatan pengenalan wajah dilakukan dengan cara membandingkan fitur wajah seseorang dengan fitur pada citra wajah yang tersimpan di dalam database [2]. Meskipun proses pengambilan data citra wajah mudah dilakukan, tetapi sistem ini ternyata memiliki banyak permasalahan yang cukup kompleks dimana sebagian masalahnya masih menjadi bahan penelitian untuk dianalisis dan dirumuskan solusinya. Permasalahan yang muncul dalam sistem disebabkan oleh banyaknya faktor yang mempengaruhi pengenalan wajah, antara lain ekspresi wajah, posisi, perubahan fisik, perubahan usia, atribut yang menutupi sebagian area wajah, jenis kelamin, pencahayaan, perubahan kualitas citra, dan sebagainya.

Salah satu faktor yang pengaruhnya sangat signifikan adalah variasi ilmuniasi, dimana cahaya yang mengenai obyek wajah saat proses pengambilan gambar akan menentukan kinerja pengenalan wajah. Wajah dari orang sama dengan posisi dan ekspresi yang sama, tetapi kondisi pencahayaannya berbeda saat pengambilan gambar, bisa jadi akan dikenali sebagai orang yang berbeda saat proses pengenalan wajah dilakukan [3]. Variasi pencahayaan ini sangat mempengaruhi tingkat kehandalan sistem pengenalan wajah [4]. Bahkan dalam situasi pencahayaan yang kompleks, pengaruh faktor pencahayaan ini lebih besar dibandingkan dengan sejumlah faktor lainnya terhadap kinerja pengenalan wajah [5]. Proses penelitian berkaitan dengan faktor pencahayaan ini masih terus dilakukan oleh banyak peneliti, khususnya pada lingkungan dengan kondisi pencahayaan yang berubah-ubah [6]. Untuk menormalisasi efek pencahayaan pada citra wajah, umumnya digunakan proses penyesuaian kekontrasan citra sehingga kinerja pengenalan wajah lebih optimal [7].

Berkaitan dengan pengenalan wajah yang dipengaruhi oleh faktor pencahayaan, banyak metode yang telah dikembangkan oleh para peneliti sebelumnya. Salah satu pendekatan yang kinerjanya cukup baik dalam menangani masalah pencahayaan dalam pengenalan wajah adalah metode Robust 
Regression [8]. Pada penelitian ini, proses pengujian dilakukan terhadap metode Robust Regression ini dengan menggunakan dataset citra wajah yang berbeda ukurannya. Secara teoritis, perubahan ukuran citra akan mengubah tingkat kekontrasan citra. Kinerja pengenalah wajah sangat dipengaruhi oleh tingkat kekontrasan citra. Sehingga perubahan ukuran citra tentunya akan mempengaruhi kinerja pengenalan wajah. Tetapi, sejauhmana mana pengaruhnya, proses pengujian secara empiris perlu dilakukan dengan menggunakan dataset citra wajah untuk mengetahui secara kuantitatif perubahan kinerjanya, sebagaimana dilakukan pada penelitian ini.

\section{Metodologi}

Bagian ini menguraikan pendekatan pengenalan wajah yang digunakan pada penelitian ini, yaitu metode Robust Regression. Uji coba dilakukan untuk mengetahui kinerja metode ini pada dataset citra wajah dengan ukuran yang berbeda. Kumpulan citra wajah yang digunakan untuk pengujian ini menggunakan salah satu database citra standar yaitu AR Face Database [9].

\section{A. Metode Pengenalan Wajah}

Secara umum, ada 3 pendekatan yang digunakan untuk memecahkan masalah pengenalan wajah yang dipengaruhi oleh faktor pencahayaan, antara lain pendekatan berbasis model, pendekatan berbasis ciri, dan pendekatan prapemrosesan.

Pendekatan berbasis model didasarkan pada subruang linier berdimensi rendah untuk mengurangi pengaruh pencahayaan pada citra wajah. Banyak citra wajah yang diperlukan untuk membangun ruang linier pada pendekatan ini, sehingga biasanya agak sulit untuk menangani basisdata yang besar. Beberapa metode yang menggunakan pendekatan ini adalah Illumination Cone [10], Spherical Harmonic [11], dan sebagainya.

Pada pendekatan berbasis ciri, proses pengenalan wajah menggunakan ciri invarian iluminasi. Beberapa metode yang menggunakan pendekatan ini adalah 2D Gabor-like Filters [12], Discrete Cosine Transform/DCT [5], Local Binary Pattern [13], dan sebagainya.

Sedangkan pendekatan pra-pemrosesan menggunakan teknik normalisasi iluminasi citra wajah sebelum proses klasifikasi pengenalan wajah. Beberapa yang menggunakan pendekatan ini adalah Quotient Image/QI, Self-Quotient Image/SQI, dan lain sebagainya. Metode Robust Regression pada penelitian ini juga menggunakan pendekatan pra-pemrosesan ini.

Pada metode Robust Regression ini, mesin pengklasifikasi berupa regressor/prediktor untuk setiap individu perlu dihasilkan melalui proses pelatihan data citra wajah. Regresor/prediktor untuk setiap individu ini merupakan kombinasi vektor latih yang dihasilkan dari matriks citra latih. Proses pengujian dilakukan untuk mengklasifikasikan data latih ke dalam salah satu kelas menggunakan regresor/prediktor (yang dihasilkan pada proses pelatihan sebelumnya). Selanjutnya matriks citra uji diubah menjadi vektor berdimensi lebih kecil dengan nilai maksimal 1 dan kelas citra uji diprediksi menggunakan hasil estimasi Huber dengan jarak terkecil.

\section{B. Dataset Citra Wajah}

Dataset citra wajah yang digunakan untuk uji coba pada penelitian ini adalah AR Face Database. Citra yang dipilih pada basisdata ini adalah citra wajah dengan ekspresi netral dan posisi wajah menghadap ke depan (tegak lurus dengan kamera saat akuisisi data). Proses pengujian menggunakan 100 orang (50 pria dan 50 wanita) dengan variasi kondisi pencahayaan. Ukuran setiap citra adalah 100x100 piksel.

Contoh citra wajah dari salah satu individu pada AR Face Database dengan berbagai variasi pencahayaan yang digunakan dalam penelitian ini ditunjukkan pada tabel 1 . Istilah "sesi" pada tabel ini menunjukkan sesi pengambilan gambar saat akuisisi citra dalam kondisi posisi dan ekspresi wajah yang sama dengan kondisi pencahayaan yang berbedabeda. Pada basisdata ini terdapat 2 sesi citra dimana setiap sesi meliputi 4 variasi pencahayaan, yaitu kondisi pencahayaan rendah (citra wajah dengan intensitas cahaya rendah dari sumber cahaya depan), sedang (citra wajah dengan intensitas cahaya sedang dari sumber cahaya samping), tinggi (citra wajah dengan intensitas cahaya tinggi dari sumber cahaya samping), dan ekstrim (citra wajah dengan intensitas cahaya sangat tinggi dari sumber cahaya depan).

TABEL I

CONTOH VARIASI PENCAHAYAAN: INDIVIDU M-001

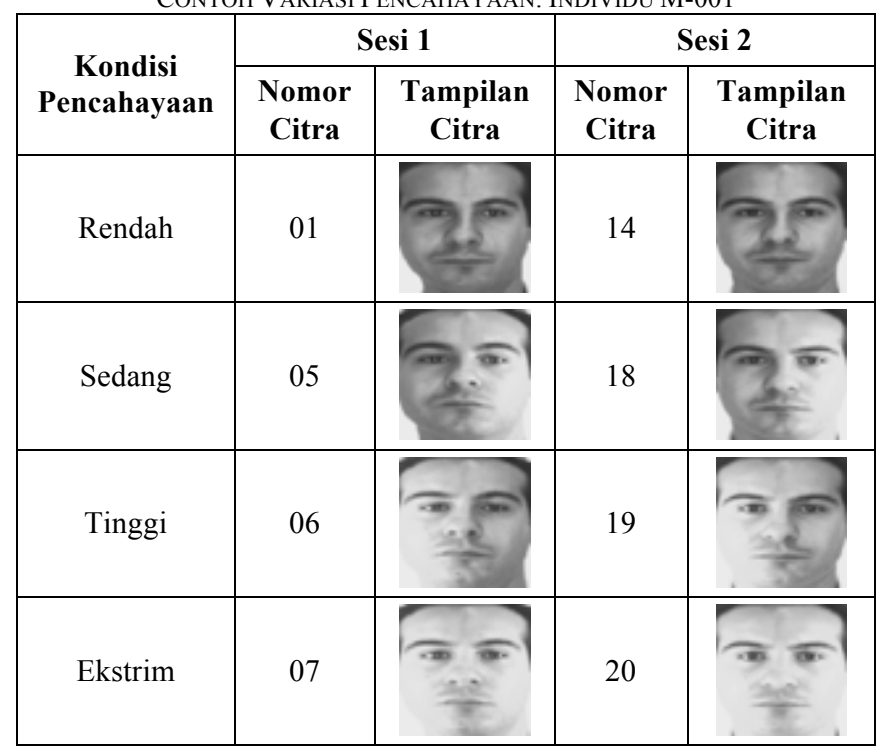

Proses uji coba dalam penelitian ini dilakukan pada setiap kondisi pencahayaan, dengan citra latih berukuran 100x100 dan 50x50, untuk mengetahui pengaruh perubahan ukuran citra latih pada setiap kondisi pencahayaan.

\section{Skenario Uji Coba}

Skenario uji coba pada penelitian ini ditunjukkan melalui tabel 2. Proses pengujian dilakukan dengan menggunakan citra latih pada kondisi pencahayaan rendah (citra 01 dan 14), sedang (citra 05 dan 18), tinggi (citra 06 dan 19), dan tinggi (citra 07 dan 20). Dalam pengujian dengan menggunakan citra latih pada setiap kondisi pencahayaan tersebut, citra uji menggunakan citra pada kondisi pencahayaan lainnya. Pada citra latih pada kondisi pencahayaan rendah, citra uji yang digunakan adalah citra 05, 06, 07, 18, 19, 20. Pada citra latih 
pada kondisi pencahayaan sedang, citra uji yang digunakan adalah citra 01, 06, 07, 14, 19, 20. Pada citra latih pada kondisi pencahayaan tinggi, citra uji yang digunakan adalah citra $01,05,07,14,18,20$. Sedangkan pada citra latih pada kondisi pencahayaan ekstrim, citra uji yang digunakan adalah citra 01, 05, 06, 14, 18, 19.

TABEL II

SKENARIO UJI COBA

\begin{tabular}{|c|c|c|c|c|}
\hline $\begin{array}{c}\text { Kondisi } \\
\text { Pencaha- } \\
\text { yaan }\end{array}$ & $\begin{array}{c}\text { Citra } \\
\text { Latih }\end{array}$ & Citra Uji & \multicolumn{2}{|c|}{$\begin{array}{c}\text { Ukuran Citra } \\
\text { (Piksel) }\end{array}$} \\
\hline Rendah & 01,14 & $\begin{array}{c}05,06,07, \\
18,19,20\end{array}$ & $100 \times 100$ & $50 \times 50$ \\
\hline Sedang & 05,18 & $\begin{array}{c}01,06,07, \\
14,19,20\end{array}$ & $100 \times 100$ & $50 \times 50$ \\
\hline Tinggi & 06,19 & $\begin{array}{c}01,05,07, \\
14,18,20\end{array}$ & $100 \times 100$ & $50 \times 50$ \\
\hline Ekstrim & 07,20 & $\begin{array}{c}01,05,06, \\
14,18,19\end{array}$ & $100 \times 100$ & $50 \times 50$ \\
\hline
\end{tabular}

Uji coba dilakukan untuk menentukan kinerja metode Robust Regression untuk pengenalan wajah dalam bentuk akurasi (satuan persen) pada setiap kondisi pencahayaan dengan ukuran citra 100x100 dan 50x50. Selanjutnya hasil pengujian pada kedua ukuran citra tersebut dibandingkan untuk mengetahui pada ukuran mana yang menghasilkan kinerja yang lebih baik.

\section{HASIL DAN PEMBAHASAN}

Pada bagian ini diuraikan hasil penelitian yang telah dilakukan berdasarkan skenario uji coba yang telah ditentukan sebelumnya. Hasil pengujian ditunjukkan melalui tabel 3.

\begin{tabular}{|c|c|c|c|c|}
\hline \multicolumn{5}{|c|}{$\begin{array}{c}\text { TABEL III } \\
\text { HASIL UJI COBA }\end{array}$} \\
\hline $\begin{array}{c}\text { Kondisi } \\
\text { Pencaha- } \\
\text { yaan }\end{array}$ & $\begin{array}{l}\text { Citra } \\
\text { Latih }\end{array}$ & Citra Uji & $\begin{array}{c}\text { Akurasi } \\
\text { (100x100) }\end{array}$ & $\begin{array}{c}\text { Akurasi } \\
(50 \times 50)\end{array}$ \\
\hline Rendah & 01,14 & $\begin{array}{c}05,06,07 \\
18,19,20\end{array}$ & $86,50 \%$ & $85,84 \%$ \\
\hline Sedang & 05,18 & $\begin{array}{c}01,06,07 \\
14,19,20\end{array}$ & $74,34 \%$ & $72,83 \%$ \\
\hline Tinggi & 06,19 & $\begin{array}{c}01,05,07 \\
14,18,20\end{array}$ & $71,34 \%$ & $70,00 \%$ \\
\hline Ekstrim & 07,20 & $\begin{array}{c}01,05,06 \\
14,18,19\end{array}$ & $94,67 \%$ & $94,83 \%$ \\
\hline \multicolumn{3}{|c|}{ Rata-rata } & $81,71 \%$ & $80,88 \%$ \\
\hline \multicolumn{3}{|c|}{ Selisih } & \multicolumn{2}{|c|}{$0,84 \%$} \\
\hline
\end{tabular}

Pada citra latih dengan kondisi pencahayaan rendah, akurasi pengenalan wajah pada ukuran citra $100 \times 100$ piksel adalah $86,50 \%$. Sedangkan pada ukuran citra 50x50 piksel, akurasinya menurun menjadi $85,84 \%$. Pada citra latih dengan kondisi pencahayaan sedang, akurasi pengenalan wajah pada ukuran citra $100 \times 100$ piksel adalah 74,34\%. Sedangkan pada ukuran citra 50x50 piksel, akurasinya menurun menjadi
72,83\%. Pada citra latih dengan kondisi pencahayaan tinggi, akurasi pengenalan wajah pada ukuran citra 100x100 piksel adalah $71,34 \%$. Sedangkan pada ukuran citra 50x50 piksel, akurasinya menurun menjadi $70,00 \%$. Serta pada citra latih dengan kondisi pencahayaan ekstrim, akurasi pengenalan wajah pada ukuran citra 100x100 piksel adalah 94,67\%. Sedangkan pada ukuran citra 50x50 piksel, akurasinya naik menjadi 94,83\%.

Pada kondisi pencahayaan rendah, sedang, dan tinggi, kinerja pengenalan wajah dengan menggunakan ukuran citra 100x100 piksel lebih tinggi daripada menggunakan ukuran citra 50x50 piksel. Tetapi pada kondisi pencahayaan ekstrim, kinerja pengenalan wajah dengan menggunakan ukuran citra 100x100 piksel lebih rendah daripada menggunakan ukuran citra 50x50 piksel. Secara visual, perbandingan ukuran kinerja pada ukuran citra $100 \times 100$ piksel dan 50x50 piksel ditunjukkan melalui gambar 1 .

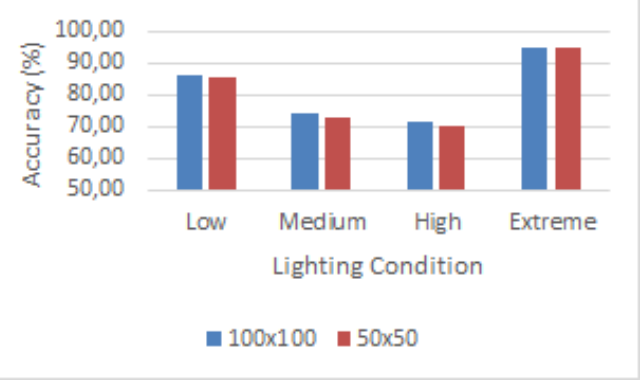

Gbr. 1 Perbandingan kinerja penegenalan wajah pada ukuran citra 100x100 piksel dan 50x50 piksel

Secara umum, kinerja pengenalan wajah dengan menggunakan ukuran citra 100x100 piksel (akurasi rata-rata sebesar 81,71\%) lebih baik daripada menggunakan ukuran citra 50x50 piksel (akurasi rata-rata sebesar 80,88\%).

\section{KESIMPULAN}

Hasil uji coba pada penelitian ini menunjukkan bahwa kinerja pengenalan wajah dengan menggunakan metode Robust Regression sanat dipengaruhi oleh ukuran citra yang digunakan pada proses pelatihan data. Pada ukuran citra yang lebih besar, kinerja pengenalan wajah menunjukkan hasil lebih baik pada kondisi pencahayaan rendah, sedang, dan tinggi. Tetapi, pada kondisi pendahayaan ekstrim (sangat tinggi), kinerja pengenalan wajah pada ukuran yang lebih kecil malah menunjukkan hasil yang lebih baik. Kesimpulan ini memberikan informasi penting bahwa pemilihan ukuran citra untuk proses pelatihan pengenalah wajah sangat penting dilakukan, agar menghasilkan kinerja pengenalan wajah yang optimal.

\section{REFERENSI}

[1] R. Jafri and H.R. Arabnia, A Survey of Face Recognition Techniques, Journal of Information Processing Systems, Vol.5, No.2, June 2009.

[2] W. Zhao, R. Chellappa, P.J. Phillips, A. Rosenfeld, Face recognition: a literature survey, ACM Comput. Surv. vol. 35, pp. 399-458, 2003.

[3] M. Singha and A.S. Arora, Varying Illumination and Pose Conditions in Face Recognition, Procedia Computer Science, 2016.

[4] Andrea F. Abate, Michele Nappi, Daniel Riccio, Gabriele Sabatino, 2D and 3D face recognition: A survey, Journal of Pattern Recognition, 2007. 
[5] Haifeng $\mathrm{Hu}$, Multiscale illumination normalization for face recognition using dual-tree complex wavelet transform in logarithm domain, Journal of Computer Vision and Image Understanding, 2011.

[6] H. Kusuma, Wirawan, and A. Soeprijanto, Face Recognition Against Varying Lighting Conditions Using Oriented Phase Congruency Image Features, Journal of Theoretical and Applied Information Technology, 2016.

[7] J. Yi, X. Mao, L. Chen, Y. Xue, A. Rovetta, and C.D. Caleanu, Illumination Normalization of Face Image Based on Illuminant Direction Estimation and Improved Retinex, PLoS One, 2015.

[8] I. Naseem, R. Togneri, M. Bennamoun, Robust Regression For Face Recognition, Journal of Pattern Recognition, 2012.

[9] A. Martinez and R. Benavente, The AR face database, Technical Report 24, CVC, 1998.
[10] Athinodoros S. Georghiades, Peter N. Belhumeur, David J. Kriegman, From Few to Many: Illumination Cone Models for Face Recognition under Variable Lighting and Pose, IEEE Transactions on Pattern Analysis and Machine Intelligence, 2001.

[11] Xiaoyue Jiang, Yinglei Cheng, Rong Xiao, Ying Li, Rongchun Zhao, Spherical harmonic based linear face de-lighting and compensation, Applied Mathematics and Computation, 2007.

[12] Al-Amin Bhuiyan, Chang Hong Liu, On Face Recognition using Gabor Filters, World Academy of Science, Engineering and Technology, 2007.

[13] Timo Ahonen, Abdenour Hadid, Matti Pietikainen, Face Recognition with Local Binary Patterns, Machine Vision Group, Infotech Oulu, Finland,

2004 . 